\title{
Birth of a Tibetan Buddhist Master, Part 1: Visionary Experiences Prior to the Birth of the Seventh Karma pa, Chos grags rgya mtsho (1454-1506)
}

\author{
Dominik DeLL
}

\begin{abstract}
This paper highlights the importance of the secret level of rnam thars accounts of visionary experiences and miraculous events as a sign of realisation in life stories of Tibetan Buddhist masters - based on existing research. The focus is mainly on visionary experiences. This paper contributes to this field by providing an annotated translation, analysis, and edition of a so-far untranslated section of the rnam thar of the Seventh Karma pa from the Chos 'byung mkhas pa'i dga'ston.

KEYWORDs: Chos grags rgya mtsho, Karmapa VII, rnam thar, secret life story, chos 'byung mkhas pa'i dga' ston, visions

Dominik Dell external PhD student at the Department of Philosophy of the Jagiellonian University, and researcher at the International Institute for Tibetan and Asian Studies, Vélez-Málaga, Spain. His research interests include life stories of Tibetan Buddhist masters of the bKa' brgyud tradition as well as their works on philosophy. He is currently preparing his $\mathrm{PhD}$ thesis on the birth stories of several Karma pas.
\end{abstract}

iD https://orcid.org/0000-0001-5816-0814

E-MAIL: dominik.dell.research@gmail.com 


\section{Introduction}

One of the most popular genres of Tibetan literature is the genre of rnam thar. ${ }^{1}$ This is short for rnam par thar pa meaning "complete liberation" or in this context rather "[story of a person's] complete liberation." There is quite a variety of English renderings of this term, all stressing different aspects of it. $^{2}$ A certain translation of the term might fit well for a certain example of a rnam thar at hand, but might fit less well for other examples of rnam thars depending on their content. ${ }^{3}$

If one looks up the Tibetan definition of this term in the Bod rgya tshig mdzod chen mo (Yísūn 1985, "rnam thar"), the first entry reads: skyes bu dam pa'i mdzad spyod lo rgyus kyi gzhung ngam/ rtogs pa brjod pa'i bstan bcos. This can be translated as: "a scripture [that provides] an account of the activities of a holy being or a treatise of [its] realisation story." The second entry states: rnam grol. This is short for rnam par grol ba, the definition of which is: sgrib pa gnyis las rnam par grol ba'o (Yísūn 1985, "rnam par grol ba"). This can be translated as: "complete liberation from the two obscurations." The two obscurations are the "afflictional obscurations" (Tib. nyon mongs pa'i sgrib pa, Skt. klesavaranam) and the "cognitional obscurations" (Tib. shes bya'i sgrib pa, Skt. jñeyavaranam). The former are the afflictions experienced by sentient beings within the cyclic existence, while the latter are the subtle obscurations that prevent the omniscience of a buddha and are experienced by all beings that have not yet reached the level of a buddha. ${ }^{4}$

What do we learn from these definitions? The first entry suggests that there are two levels of a rnam thar, the first being a mere account of what an excellent being (Tib. skyes bu dam pa) or holy person, i.e., some kind of Buddhist master, actually did during his lifetime. This corresponds very

1 I would like to thank Artur Przybysławski, who encouraged me to write this paper and who kindly provided some feedback on an earlier version.

2 For instance "biography," "spiritual biography," "sacred biography," "life story," "liberation story," "spiritual story," "life example," "hagiography," "(hagiographic) life writing" and some more. For enumerations and discussions of different English renderings, see also Roesler 2014, 117, as well as Rheingans 2014, 69f., and Rheingans 2010, $252 \mathrm{f}$.

3 Roesler 2014, 117f. describes a variety of possible content of rnam thars in her article such as Tibetan operas, novels and religious instructions. Also Rheingans, 2014, 60 enumerates different kinds of content. According to him "[hagiographies range] from informative life accounts to tantric instructions, eulogies, and even works containing empowerment rituals." On the same matter, see also Rheingans 2010, 252.

4 Duff 2009, “sgrib pa gnyis.” For a similar classical argumentation, see also Jamgön Kongtrul Lodrö Thayé 2003, 3. 
much to our usual understanding of the notion "biography" apart from the fact that it is limited to a certain group of protagonists - the skyes bu dam pa. Considering this the notion "hagiography" might fit quite well. In the Oxford dictionary it is defined as "the writing of the lives of saints." ${ }^{5}$ Of course, "saint" is originally meant in the Christian context, but if we consider the skyes bu dam pa as the equivalent to a saint, then this term from our Western cultural context covers the meaning appropriately. The second level suggested by the rnam thar definition goes beyond a mere account of someone's deeds - it is the description of the realisation (Tib. rtogs pa) of a skyes bu dam pa, i.e., it focuses on the spiritual development of a person, who has reached a level that he or she can serve as an example for others. This level, which is to be reached, is "complete liberation" (Tib. rnam thar), which gives the name to this genre. The second entry (Tib. rnam grol) then specifies further what this complete liberation means - "complete liberation from the two obscurations."

These definitions clarify that the functions of this genre go beyond mere provision of historical or biographical facts about a person. Thus, it evidently exceeds the Western concept of biography. However, it also transcends the Western or Christian concept of hagiography, to which the concept of "complete liberation" is foreign. ${ }^{6}$ The genre of rnam thar has been classified in various ways. The most prominent and classical divisions are probably the outer, inner, and secret levels. ${ }^{7}$ Secret life stories (Tib. gsang ba'i rnam thar) contain mystic events experienced by the protagonist, such as miraculous dreams, visionary experiences, and supernatural phenomena - all of them representing realisation of the nature of mind. The section of the Seventh Karma pa's life story, which is to be translated and analysed in this paper, contains visions, visionary dreams and prophecies and hence belongs to the third division, the secret level. Therefore, I would like to investigate the function of rnam thars especially with respect to this third level and especially to what we might call visionary experiences.

Oxford Dictionaries, "Hagiography" (Accessed: 15.01.2020).

6 Of course, depending on one's focus, it can make sense to consider rnam thars as hagiographies, especially from the point of view of comparative religious studies. For instance, Robinson $(1996,65)$ mentions characteristics of the transmission of hagiography over time, where he refers to the Catholic scholar Delehaye (1962), who has identified such based on the accounts of the lives of Christian saints. These characteristics also apply to the Tibetan rnam thars.

7 Vostrikov 1994, 186f. This classification is ascribed to sDe srid Sangs rgyas rgya mtsho (16531705). For a brief and accessible explanation of the three levels, see also Choegyal Gyamtso Tulku 2000, 21-22. 
Willis $(1995,5)$ considers a rnam thar as "a piece of tantric literature [that presents] the significant experiences of a tantric adept in his or her quest for enlightenment." Thus, the main function is "the imparting of esoteric and exoteric practice descriptions and instructions." third level - the secret life story - as a key element to this and proposes to view it "as providing inspiration and encouragement." (Willis 1995, 5). Willis quotes a Buddhist master asked about the benefit of reading rnam thars and its function. The latter holds that they are most "useful and interesting when associated with one's own practice" (Willis 1995, 16). She explains that before the introduction of a new teaching or a set of initiations, lamas usually narrate rnam thars of masters that practised the method successfully. She concludes that "[the] recitation of namtar sets the stage for practice by giving authority and credence to the lineage of teachings, by prefiguring the conditions conducive to practice, and by subtly sowing the seeds for similar liberation" (Willis 1995, 16).

In order to truly inspire, the protagonist of a rnam thar must not be too different from ourselves. The given example must be replicable. The identification with the hero of a rnam thar is very much related to the role and importance of the lama in Tibetan Buddhism and to the concepts of guru devotion and guru yoga. ${ }^{9}$ If one views secret life stories as tantric texts, this means that the descriptions in them are not necessarily to be taken literally. They are full of symbolism and "ordinary language is called upon to function in an extraordinary way to suggest the richness, the taste, of a reality that is ultimately ineffable" (Willis 1995, 20).

This last quote might also be applied to the occurrence of visions in rnam thars. In Tibetan, visions are referred to by the terms gzigs, gzigs snang or zhal gzigs. Another term that is frequently used is dag snang-"pure vision" (Gyatso 1981, 65; Verhufen 1992, 49). According to tradition there are three types of visions: visions in reality (Tib. dgnos), meditation (Tib. nyams) and dream (Tib. rmi lam) (Gyatso 1981, 72; Verhufen 1992, 50). The origin of visionary experiences in Tibetan accounts can be found in Indian Buddhism of the first century CE. The sutras and other Buddhist scriptures of that

8 Willis 1995, 5. See also Willis 1985, 308, where she claims exactly this to be a major difference between rnam thar and Western hagiography. According to her rnam thar "do more than just inspire and edify, they instruct as well, setting forth, albeit in veiled language, detailed descriptions of practice and instructions for future practitioners of the Path."

9 For further elaborations on the role of the lama and the devotion to him see Willis 1995, 16-18. For the relationship between teacher and disciple in Tibetan Buddhism, see also Verhufen 1992, 43ff. 
time contain many examples of spontaneous visions where the buddhas and bodhisattvas are in direct personal communication with the adept (Gyatso 1981, 66). These visionary experiences were then systematised by creating sādhanas, practices where the practitioner visualises that he has become a buddha or that a buddha is in front or above him and through that he has attained the realisation of enlightenment. In this way, sādhanas can be seen as an attempt to cause or control visionary experiences. However, the difference between active visualisations and passive visionary experience should be noted (Gyatso 1981, 67). According to Tibetan understanding, the visionary experiences described in rnam thars are a continuation of the Indian tradition. For them it is natural that an advanced practitioner meets with enlightened beings (Gyatso 1981, 67-68). Ray argues in the same direction. According to him those visions are not mystic in our Western sense, but actually quite ordinary. He describes them as "the overtones of ordinary experience that are usually hidden from the eye" (Ray 1980, 4). The key to understand this is to acknowledge that "it is consistent with the general Buddhist view that there is no other reality than that which presents itself immediately to experience" (Ray 1980, 4). This even applies to the vision of buddhas and pure realms. The path to come to such experiences is several levels of preparation and meditation training. ${ }^{10}$ From these considerations it clearly follows that, if a vision is described in a rnam thar, this is a claim on the attainment of the one who experiences it.

Gyatso even presents a Tibetan system of seven types of authentic transmission where "pure vision" (Tib. dag snang) is one of them ${ }^{11}$, i.e., visions are an accepted means of obtaining new teachings, instructions, and methods directly from a buddha or bodhisattva. Verhufen $(1992,51)$ notes that the bKa' brgyud tradition always emphasised the importance of visions already starting with Marpa and Milarepa. ${ }^{12}$ This also applies to the life stories of the Karma pas. Ray even holds that "[one] could well say that to tell the story of the significant events in the life of a Karmapa is to recount those visions, with the understanding they embody and the activity they produce. In fact, it is those visions that form the main subject matter of these biographies" (Ray 1980, 3).

${ }^{10}$ Ray (1980, 3-9) provides extensive explanations on the different levels of training and how this is all related.

11 The others are the commonly known 'spoken transmission' (bka' ma), four kinds of 'discovered treasures' (gter ma), and the whispered transmission (snyan brgyud). For more information about the different kinds of authentic transmission, see Gyatso 1981, 64-65.

12 For an example of Milarepa, see Evans-Wentz 1969, 217-18. For Marpa's famous visionary dream of Saraha, see Tsang Nyön Heruka 1982, 42-48. 
Summing up, visionary experiences in the life story of a Buddhist master demonstrate his or her attainments. They are considered as natural result of meditational training showing a layer of reality that is invisible to the untrained. They serve as a means of inspiration to the audience of rnam thars, the practitioner who aspires after the given example. Here the concept of guru devotion and the identification with the teacher - one of the characteristic features of Tibetan Buddhism - plays an eminent role.

\section{Translation}

\subsection{Introduction to the translation}

The Seventh Karma pa's life story in the mKhas pa'i dga'ston starts with his bar do'i rnam thar - his account of the intermediate state between his sixth and seventh incarnation. ${ }^{13}$ The section to be translated here starts right after the bar do'i rnam thar and mainly contains prophesies, visions, dreams and miraculous events that happened prior to the birth of the Seventh Karma pa. For easier reference, I inserted the page numbers of the three textual witnesses used for the edition into the translation - those from the original block print (A) ${ }^{14}$ those from one of the book versions (B) ${ }^{15}$ and those from Chandra's handwritten edition $(\mathrm{C}) \cdot{ }^{16}$ For an overview of all texts used, see the introduction to the edition in the appendix. I divided the translation into three sections by inserting titles, which I refer to in the analysis section. ${ }^{17}$

The type of translation provided here is an annotated translation, i.e., it uses footnotes to explain terms and concepts that the general reader might be unfamiliar with. Furthermore, it provides references for personal and place names that appear in the text. In cases where the Tibetan text is unclear or ambiguous, choices of translation are also discussed. In this context, I would like to thank Āchārya Choying Tendar for explaining to me various terms and phrases in the Tibetan text, which at first sight seemed obscure to me.

${ }^{13}$ For a translation and discussion of this section, see Dell 2020.

${ }^{14} \mathrm{dPa}$ ' bo gtsug lag 'phreng ba 1980, vol. 2, 186-88.

${ }^{15} \mathrm{dPa}$ ' bo gtsug lag 'phreng ba 1986, vol. 2, 1033-35.

${ }^{16}$ dPa' bo gtsug lag 'phreng ba 1959-1965, vol. 2, 538-39.

17 In the footnotes of the following annotated translation, as well as in the bibliography, I will often refer to the Buddhist Digital Resource Center (BDRC), https://www.tbrc.org/ (Accessed: 05.01.2020), by using the acronym BDRC followed by an alphanumerical code by which the person, location or work can be found in the BDRC database. 
A few words on the conventions applied: in case of some technical terms and names of buddhas for which there is a Sanskrit equivalent, I tend to use the Sanskrit term or name, rather than the original Tibetan or an English rendering, but in any case those are annotated. Sanskrit terms that are found in an English dictionary are written without diacritics. Parts of the translated sentences that are not directly found in the Tibetan, but that had to be supplemented, are written in square brackets.

\subsection{Annotated translation}

\subsection{1. [Prophesies and dreams prior to the Karma pa's birth]}

$\mathrm{Also}^{18}$ the great 'Jam dbyangs [from] mTshur $\mathrm{phu}^{19}$ said at a certain time in the seventh month of the bird year (1453) to the many [monks sitting in] rows [having] tea: ${ }^{20}$ "According to my dream now someone called dPal grup became the father of the tulku."

Likewise Kun mkhyen ban sgar $\mathrm{ba}^{21}$ prophesied that the tulku would appear straight in the Eastern direction [seen] from mTshur phu. ${ }^{22}$

$[B, p .1034]$ At that place, [where he] was going to take birth, there [were] fragrances of fine smells [and] rains of flowers. Since to all laymen and monks there appeared many extraordinary dreams, [they] talked about what kind of thing this was.

18 The bar do'i rnam thar that precedes this section ends with the following sentence: "In the North Amoghasiddhi said: 'You will be born into the world from the father, Grags pa dPal grub, and the mother, lHa mo skyid"' (Dell 2020, 51). Thus, it predicts the names of the parents. Here another reference is given to the name of his father. That's why this sections starts with "also."

19 Probably, mTshur phu 'Jam dbyangs chen po Don grub 'od zer, also known as Go shri' don grub 'od zer, see: BDRC, P1417. He was the abbot of mTshur phu monastery until 1449. For more information, see Schuh, 2010 (Accessed: 06.02.2020).

20 Tib. ja gral ba mang du yod pa zhig. According to Āchārya Choying Tendar (oral communication in July 2015), monks tend to sit in rows while doing püjas and very often they have tea at the same time. This term might refer to such a situation. However, he claims that part of the sentence is within the dream that is described here, but also admits that it is not clearly related to what follows. I do not agree with him. I think the term refers to the persons that are addressed by mTshur phu 'Jam dbyangs talking about his dream.

${ }^{21}$ BDRC, P467 (Ban sgar ba 'Jam dpal bzang po). He was a close disciple of the Sixth Karma pa and a teacher of the Seventh Karma pa.

${ }^{22}$ mTshur phu dgon is the "chief monastery of the KaM tshang bka' brgyud pa in Central Tibet located to the north of lHasa" and the seat of the Karma pas (BDRC, G33). 


\subsection{2. [Circumstances of the conception and wondrous events and visions connected to the tulku in the womb]}

Accordingly, [the Karma $\mathrm{pa}^{23}$ ] knew that the time to tame [his future students had come] and [he] looked ${ }^{24}$ at the parents and the place [of birth] that had been prophesied previously. At the beginning both [the Karma pa's] father, the siddha of the tantric practice ${ }^{25} \mathrm{Grags}$ pa dPal grub and [his] mother, the natural yogini, ${ }^{26}$ Jo da bza' 1 Ha mo skyid, lived in [a place] called $\mathrm{O}$ rgyan ri $\mathrm{khrod}^{27}$ as powerful hidden yogins. ${ }^{28}$ [They] set all beings on [the level of] Vairocana ${ }^{29}$ through the activity of the six doors ${ }^{30}$ in accordance with the Yogatantra ${ }^{31}$ and out of the five types of supreme enlightened wisdom ${ }^{32}$ of the Anuttarayogatantra ${ }^{33}$ [they] visualised the mother's womb, the pure palace, as the essence of Vairocana, the principal

${ }^{23}$ The honorific verbs mkhyen and gzigs indicate that it is the Karma pa who "knows" and "looks at" in this context.

24 This paragraph obviously takes up the previously recounted bar do'i rnam thar (Dell 2020, 48-51), i.e. the Karma pa "looks" from the bar do state.

25 Tib. snags spyod kyi grub thob.

26 Tib. rang bzhin gyi rnal 'byor ma.

27 This is the name of a hermitage founded in 1499 by Grub thob bKra shis dpal (BDRC, G1958). The Seventh Karma pa was born in 1454, but this could still be the same place or area.

${ }_{28}$ Tib. sbas pa'i rnal 'byor, "hidden yogins." This probably means that outwardly they lived like normal people, but secretly they did their tantric practice.

29 Tib. rnam snang or long rnam par snang mdzad, name of the buddha at the head of the buddha family.

30 Tib. sgo drug, lit. "six doors." This probably refers to the six sense doors: eyes, ears, taste, touch, body and mind. It could also refer to the term sdig pa'i sgo drug - the six doors of negative actions - which are "six aspects to be contemplated during the practice of regretting one's negative actions." See: Rigpa Wiki contributors, "Six doors of negative action." For more information, see also Khenpo Ngawang Pelzang 2008, 228-29.

31 Tib. rnal 'byor gyi rgyud, the third of the six levels of tantra and the third of the three outer tantras in the old translation school (Duff 2009, rnal 'byor gyi rgyud).

32 Tib. byang chub pa'i ye shes rnam pa lnga or just briefly ye shes lnga, "the five wisdoms," 1) me long ye shes, "mirror-like wisdom," 2) mnyam nyid ye shes, "equality wisdom," 3) sor rtog ye shes, "individually discriminating wisdom," 4) bya grub ye shes, "all-accomplishing wisdom," 5) chos dbyings ye shes, "dharmadhātu wisdom," (Duff 2009, byang chub pa'i ye shes rnam pa lnga). Those five wisdoms are connected to the five conqueror families, rgyal ba rigs lnga, explained in one of the subsequent footnotes.

33 Tib. rnal 'byor bla na med pa or rnal 'byor bla na med pa'i rgyud, "unsurpassed yogatantra," in the new tantra system, the fourth and highest of the four tantra sections (Duff 2009, rnal ’byor bla na med pa). 
figure of the physical manifestation of all [buddha] families. ${ }^{34}$ The fortunate lord of the yogins ${ }^{35}$ acted as [giving] as many ripening [empowerments] and liberating [instructions] ${ }^{36}$ as there are atoms of Mount Meru, ${ }^{37}$ but from the point of view of the virtues of those who see [only] "this side" 38 - those with [only] a little bit of fortune - [the situation appeared as follows]: after entering the mother's womb, the mother's complexion, behaviour etc. appeared as even more noble than before [A, p. 187]. At that time the Earth at the mother's [location] shook slightly and [her] body was constantly surrounded by rainbows. The blissful warmth was blazing [in her body ${ }^{39}$ and she] retained the clear light ${ }^{40}$ without effort.

Also in [her] dreams [she] met again and again with the master mThong ba don ldan. It was said [in her dreams] that the self-arisen [image of] Brag lha

34 Tib. rigs or rgyal ba rigs lnga, "the five conqueror families," "the five families of the conquerors." Their names in Tibetan and Sanskrit are: 1) rnam par snang mdzad, Vairochana, 2) mi bskyod pa, Akșhobya, 3) rin chen 'byung gnas, Ratnasaṃbhava, 4) snang ba mtha' yas, Amitābha, 5) don yod grub pa, Amoghasiddhi (Duff 2009, rgyal ba rigs lnga). All of those buddha names already appeared in the bar do'i rnam thar preceding this section (Dell 2020, 49-51).

35 This term probably refers to the father who blesses the form created in the mother's womb in the previous sentences during the process of conception. It could also refer to the father and the mother together.

${ }^{36}$ Tib. smin grol, abbreviation of smin byed kyi dbang, "ripening empowerments," and grol byed kyi khrid, "liberating instructions," two necessary aspects of the secret mantra vehicle (Duff 2009, smin grol).

37 Tib. ri rab, translation of the Skt. meru, "the name of the huge mountain which is at the centre of world systems of our type according to Buddhist cosmology" (Duff 2009, ri rab).

38 Tib. tshu rol, lit. "this side" as opposed to pha rol, "the other side," also used as an epithet for "cyclic existence," samsāra (Duff 2009, tshu roI), however, from the context given here it rather refers just to ordinary people (in contrast to the Karmapa's parents), who cannot see how the parents were acting during the conception, but they just see some little outer changes of the mother.

39 Tib. bde drod 'bar. This is one of the so-called three blazings ('bar ba gsum) which are seen as "the manifestations of spiritual attainment: (1) blazing blissful warmth in the body (lus la bde drod 'bar ba); (2) blazing power of speech (ngag la nus pa 'bar ba); and (3) blazing of the realisation in the mind (sems la rtogs pa 'bar ba)" (Khenpo Tsewang Dongyal 2008, 311).

40 Tib. 'bar 'od gsal. See Duff 2009, for a discussion of the term 'od gsal (ba). He claims that "clear light" is a misunderstood translation and it should rather be "illumination." To avoid such discussions one may choose the Sanskrit term. Nevertheless, I use the term "clear light" here, as it has become a common translation. 
mgon $\mathrm{po}^{41}$ which was located at the hill behind ${ }^{42}$ was her ${ }^{43}$ accomplishment. Then $\left[\right.$ she $\left.^{44}\right]$ put a relic statue of Vajradhāra, ${ }^{45}$ a golden dorje, ${ }^{46}$ and a crystal stupa - [which she had] found - into [her] womb. ${ }^{47}$ [She] only dreamt of pure visions ${ }^{48}$ such as the presence of many suns and moons.

On the eighth day of the third month many sounds of music were heard three times in the sky. Since [the Karma pa] did a yogic exercise ${ }^{49}$ in the womb, the mother's body shook.

On the twenty-eighth [day] of the sixth month the mother clearly heard [the Karma pa] uttering the six syllables [of the mani mantra ${ }^{50}$. After that all

${ }_{41}$ Tib. brag lha mgon po, lit. "rock deity protector." Āchārya Choying Tendar (oral communication in July 2015) insists that this is a form of Mahākāla. Also de Nebesky-Wojkowitz lists Brag Iha mgon po as one form of Mahākāla. "[He] wears a diadem of five skulls, a garland of fifty-one human heads, the lower part of his body is covered by a loin-cloth made of tiger-skin, and over it he wears a cloak of black silk. He stands with the right foot bent and the left stretched out" (de Nebesky-Wojkowitz 1996, 63).

42 Tib. rgyab ri. This is a terminus technicus from Tibetan Geomancy (Tib. sa dpyad) referring to the hill or mountain behind a building and plays an eminent role in finding the optimal place for the erection of a building. Hence, here it refers to a hill behind the place where the parents lived. In the passage following this translation, there is a rather extensive description of the future birthplace which strongly draws from the principles of Tibetan Geomancy. For a translation and discussion, see Dell 2021.

43 Tib. khong rang either refers to the mother ("her") or alternatively to the Karmapa ("his"). In the translation I decided for "her."

${ }^{44}$ The fact that a non-honorific verb form (bcug) is used in this sentence indicates that it is the mother and not the Karma pa who acts here.

45 Tib. rdo rje 'chang.

${ }^{46}$ Tib. rdo rje. Skt. vajra. Ritual sceptre used widely in Vajrayana.

47 Tib. pang khug. In text A and B the spelling is pung khug, whereas in the handwritten text $\mathrm{C}$ it is bud khug, which might be a sloppy handwriting for pung khug as in Tibetan letters this looks very similar. I was unable to find this term in any dictionary, but according to Āchārya Choying Tendar (oral communication in July 2015) it means "armpit." This could correspond with the literal meaning of the two syllables the term is made up from: pung means "urn-shaped vessel" and khug means "recess" or "nook," so together it might mean "armpit." Nevertheless, from the symbolic point of view it is not so meaningful that she puts those things under her armpits. If one assumes a misspelling and reads pang khug instead of pung khug, then this comes to mean "womb" (literally "lap recess," see: Duff 2009, for the two syllables). Then she would put those things into her womb, which might be a symbol for her conception. Even, if one does not assume a misspelling the term, pung khug could also come to mean "womb" considering the meanings of the constituents as given above.

48 Tib. dag snang.

49 Tib. 'phrul 'khor. According to Āchārya Choying Tendar (oral communication in July 2015) this is the short name of a practice called rtsa rlung 'phrul 'khor. It is a "practice of physical yoga in which breath and mental concentration are integrated with particular body movements" (Chaoul 2007, 70). Information about this practice is also found in Lipman 1987, and as an original Tibetan source, Mar pa lo tsā ba and dPal 'byor don grub 1995.

${ }^{50}$ oM ma Ni pa+dme $h U \sim M$. 
[people] that were closely around heard the uttering of the string of vowels and the string of consonants of the Sanskrit alphabet ${ }^{51}$ and the six syllables [of the mani mantra] at all auspicious occasions.

During the mother's collection of wood [she] fell and got struck, therefore, [the Karma pa in the womb ${ }^{52}$ ] said: "Ow, ${ }^{53}$ what did [you] do?" [B, p.1035]

While the mother was taking a drink, [the Karma $\mathrm{pa}^{54}$ ] did a yogic exercise. Therefore, [she] spilled ${ }^{55}$ the drink.

A girl gave a black hat [to her] and Vajrayogini ${ }^{56}$ said: "In your body there is the foetus ${ }^{57}$ of the Karma pa." [And] Avalokiteśvara ${ }^{58}$ with one head, four arms and white body colour appeared dwelling inside [her] empty heart centre. The three joints of the middle finger of [her] right hand appeared as the protectors of the three families ${ }^{59}$ and [she] saw Avalokiteśvara ${ }^{60}$ most clearly and the other two a little less clearly.

[Her] visions of such pure appearances in reality, [meditative] experience and dreams ${ }^{61}$ were beyond limits.

It was said: "A white man will blow a large conch which will be heard everywhere. Don't stay here, go to rNgod A la." ${ }^{2}$

\subsection{3. [Wrapping up the events in place and time from before the conception until arrival at the future place of birth]}

Before that, when the father resided in the lower South in order to practise, a lama made a prophecy in a dream [A, p. 188]. [He] said: "Go to O rgyan ri

51 Tib. A' li k'a li.

${ }^{52}$ Since the honorific verb gsung is used, it is clear, that it is the Karma pa who speaks here.

53 Tib. A na na. According to Jäschke (1998), this is "an interjection expressive of grief"

54 The honorific verb mdzad indicates that the action is done by the Karma pa and not by the mother.

${ }_{55}$ Tib. bo is a verb meaning "to spill" in Kham dialect (Duff 2009, bo ba).

56 Tib. rdo rje rnal 'byor ma.

57 Tib. 'khrung rgyu yod. More literal: "Your body has the Karma pa for being born" or "In your body there is the Karma pa for being born."

58 Tib. spyan ras gzigs.

59 Tib. rigs gsum mngon po, the protectors of the three families are Mañjuśrī, Avalokiteśvara and Vajrapāni (Duff 2009, rigs gsum mngon po).

${ }^{60}$ The mention that she sees Avalokiteśvara most clearly might be an allusion to the fact that her future son, the Karma pa, is generally considered as an emanation of Avalokiteśvara.

61 Tib. dgnos nyams rmi lam.

${ }^{62}$ There is a place called rNgod A la rong (see BDRC, G4881), where rNgod is an area in or near Kong po, (see BDRC, G4880). This place is also mentioned as the birthplace of the Fourth Karma pa (see BDRC, P1456). 
khrod [and] infinite benefit for beings will occur." [This] having been said, immediately at the arrival also to the mother a prophecy occurred. When [she] arrived there, a fragrance of fine smells spread everywhere. A boy with whitish skin ${ }^{63}$ being present in [her] dream said: "[I] am the dharma master Karma pa." Thereafter, [her] pure visions [were] beyond limits and visions that [she] was inseparable from the master Karma pa came up all the time.

A prophecy to go to sPyi mda' in the $\mathrm{rNgod}^{64}$ [area] came up again and again.

Later on, both dreamt that at the place of taking birth there was a pair of sun and moon and [they] dreamt of acquisitions such as gold bars. ${ }^{65}$ [They] arrived in the rNgod [area]. Realising that [they] were at the place that had appeared [to them] in the dream, they stayed at sPyi mda'i mkhar. ${ }^{66}$

\section{Analysis}

Having presented an annotated translation in the previous section, I would like to supplement it by further analysing the text in this section. The content of all three paragraphs is summarised and the major events are analysed by explaining them against the background of other research or tradition or by relating them to other sources. Finally, possible functions of certain paragraphs are discussed.

${ }^{63}$ Tib. sha rtsi, "skin colour." All three source texts read sha rtsa ("flesh and veins") here which has been emended by me to sha rtsi. The meaning is similar in both cases, but "flesh and veins" sounds rather unusual in English. In any case, it is about the outer appearance of his body.

${ }^{64} \mathrm{rNgod}$ is an area in or near Kong po (BDRC, G4880).

${ }^{65}$ The blockprint (A) reads gser sbram brnying pa sogs, which could be emended to gser sbram rnying pa sogs as brnying is not found in any dictionary - "old gold bars and other things" (Goldstein, Shelling, and Surkhang 2001, "gser sbram”). However, the book version (B) reads gser sbram rnyed pa sogs - "gold bars [and] other acquisitions" or "acquisitions such as gold bars." The handwritten text (C) reads gser sbram brnyed pa sogs where brnyed is not found in any dictionary, but it could be emended to what text B reads. Hence, it seems that both B and $\mathrm{C}$ could not make sense of the original reading of $\mathrm{A}$, but came up with the same emendation. I follow them, since I cannot make much sense of the word "old" in "old gold bars."

${ }^{66}$ Same place as sPyi lha, the birthplace of the Seventh Karma pa, as mentioned before in this rnam thar (Dell 2020, 48). 


\subsection{Prophesies and dreams prior to the Karma pa's birth}

Concerning this rather short paragraph, the following content is to be analysed: ${ }^{67}$

- Great 'Jam dbyangs from mTshur pu: dream prophesy of the Karma pa's father;

- Kun mkhyen ban sgar ba: prophesy of the Karma pa's place of birth;

- At the Karma pa's future birthplace there are a rain of flowers and fine fragrances, and many people have extraordinary dreams.

The Great 'Jam dbyangs from mTshur pu (b. $14^{\text {th }} / 15^{\text {th }}$ century ${ }^{68}$ was the abbot of mTshur phu monastery until 1449, the chief monastery of the Karma bka' brgyud in Central Tibet, founded by the First Kama pa, Dus gsum mkhyen pa (1110-1193), ${ }^{69}$ in $1189 .{ }^{70} \mathrm{He}$ is said to have already been a student of the Fifth Karma pa, De bzhin gshegs pa $(1384-1415),{ }^{71}$ but his lifespan obviously overlapped completely with that of the Sixth Karma pa, mThong ba don ldan (1416-1453). ${ }^{72}$ Kun mkhyen ban sgar ba (b. 15th century) was a close disciple of the Sixth Karma pa and transmitted special teachings from the Karma pa's sixth to his seventh incarnation..$^{73}$ Both had a close relationship to the Sixth Karma pa and were considered highly realised. Taking into account that, according to tradition, visions (including visionary dreams) are a sign of realisation - as argued in the introduction - it is consistent that those two have predictive dreams about the parents and the place of birth of the Seventh Karma pa.

Additionally, at the place where he is to be born there are fine fragrances and a rain of flowers, about which many ordinary people - laymen and monks - have extraordinary dreams. Fragrances and a rain of flowers are a characteristic already found in the Buddha's birth story and signify the presence of beings from the god realms showing their veneration. ${ }^{74}$ Within the given context, extraordinary dreams can be counted as visions. However, in this case at hand it is not the master with extraordinary attainments who

${ }^{67}$ dPa' bo gtsug lag 'phreng ba 1986, vol. 2, 1033-34.

${ }^{68}$ BDRC, P1417.

69 BDRC, P1400.

${ }^{70}$ BDRC, G33.

${ }^{71}$ BDRC, P1410.

72 BDRC, P1006.

73 BDRC, P467, and Gardner 2011 (Accessed: 02.02.2020).

${ }^{4}$ Dharmachakra Translation Committee, 2013, paragraphs 7.21, 7.33, 7.37, 7.59, 7.150 (for flowers) and paragraphs 7.25, 7.29, 7.49, and 7.63 (for fragrances). 
has a visionary experience, but many rather ordinary people just because they are at the future birthplace. This is an example where the closeness of a high master causes visions in ordinary people. Thus, in this case the visions can be considered as a sign of the abilities of the Karma pa. ${ }^{75}$

\subsection{Circumstances of the conception and wondrous events and visions connected to the tulku in the womb}

This paragraph touches a lot of topics to be commented here ${ }^{76}$ :

- From the intermediate state Karma pa sees that it is the right time to come;

- Descriptions of his future parents as hidden yogins living in O rgyan ri khrod who did all kinds of tantric practices and who accumulated immeasurable merit;

- Description of meditative conception visualisation; for ordinary people: change of complexion and behaviour of the mother to even more superior after the conception;

- Shaking of the Earth at the conception and the mother constantly surrounded by rainbows;

- Blazing of blissful warmth in the mother's body and retaining of the clear light effortlessly;

- Frequent meetings with the Sixth Karma pa in the mother's dreams (examples given); only dreams of pure visions;

- Third month: sounds of music in the sky; shaking of the mother's body due to Karma pa's yogic exercise in the womb;

- Sixth month: Karma pa utters the mani mantra and the Sanskrit alphabet repeatedly, also heard by other people;

- Vision of Vajrayogini prophesying that the Karma pa is in her womb; visions of Avalokiteśvara;

- Limitless visions of pure appearances in reality, meditative experience and dreams;

- Vision to go to rNgod A la.

This paragraph starts with the Karma pa looking from the bar do state upon the world. The mention that the Karma pa sees that it is the right time to come into the world underlines that nothing connected to the Karma pa

75 See also Verhufen 1992, 50, who detects similar situations.

${ }^{76}$ dPa' bo gtsug lag 'phreng ba 1986, vol. 2, 1034-35. 
happens by accident, but everything is under his control, fits with the needs of beings, and is his conscious decision. This is also true for the Buddha.

His future parents are described as hidden yogins and tantric practitioners, who accumulated immeasurable merit. Their accomplishments and abilities are mentioned extensively. This emphasises that they are extraordinary and therefore suitable as parents for such a high lama as the Karma pa.

The actual conception is described as a meditation practice where the parents visualise "the mother's womb, the pure palace, as the essence of Vairocana, the principal figure of the physical manifestation of all [buddha] families." This is a far cry from the usual idea of conception and shows that not only the Karma pa comes consciously into this world, but that also the parents to-be consciously invite a highly realised being to enter the womb of the mother, for her to eventually give birth to him. It is also mentioned that ordinary people could not see such miraculous occurrences, but still they perceived a change in the complexion and behaviour of the mother as even better after the conception. This again suggests that the level of perception of reality depends on one's own realisation. The mother's womb is here described as a "pure palace." In the birth story of the Buddha a similar image is used. There it is said that "a temple of precious materials is manifested on the right side of the mother's womb," where he entered consciously coming from Tusita heaven. ${ }^{77}$

At the conception, the Earth shakes and the mother is constantly surrounded by rainbows. These are classical miraculous signs already found in the life story of the Buddha at his conception (Kieschnik 2004, 541). The change in the mother's complexion after the conception is another one. It is also described that the Karma pa's mother had many dreams where she met with the Sixth Karma pa around the time of the conception. In one of those dreams, she finds three precious objects, which she puts into her womb: a relic statue of Vajradhāra, a golden dorje (Tib. rdo rje), and a crystal stupa. This seems to be a symbol for her conception. Similarly, the Buddha's mother dreams that a white elephant enters her womb and this is said to have been her conception (Kieschnik 2004, 541).

Conception dreams are frequent in rnam thars of Buddhist masters and can be regarded as allusions to the Buddha's mother's conception dream though differing in details. ${ }^{78}$ Young describes and interprets several conception dre-

77 Dharmachakra Translation Committee 2013, paragraph 6.46.

78 For more examples and interpretations of conception dreams, see Young 1999, 73-86, who dedicates a whole book chapter on the topic. 
ams in her book. It is rather frequent that the future mother sees a statue of a certain buddha entering her womb (Young 1999, 80). In this case the statue of Vajradhāra, the essence of all male buddhas, clearly symbolises the Karma pa. Concerning the dorje that appears in conception dreams, Young says: "Vajra or dorje refers mainly to the ritual object representing the male aspect of tantric practice, though it here also symbolizes a male practitioner. It is a preeminent symbol for the active force or energy of universal compassion and one that frequently appears in other Tibetan dreams" (Young 1999, 77) ${ }^{79}$ Concerning the stupa, Young also presents examples from conception dreams of Mandārāva and Ye shes mtsho rgyal, Padmasambhava's consorts. She describes stupas as "womblike receptacles" representing the female aspect and at the same time a "stupa is considered an emanation of the Buddha's mind," and an "appropriate symbol to represent a Buddhist hero." ${ }^{80}$ Young also refers to Milarepa's rnam thar where his spiritual father Marpa dreams of a dorje and his spiritual mother Dakmema of a crystal stupa before his arrival (Young 1999, 83). So this can also be considered a conception dream and the dream at hand might also be an allusion to this, as Marpa is one of the spiritual forefathers of the Karma pa lineage.

It seems to me that different levels of symbolic meaning can be identified in the conception dream at hand. If the statue symbolises the Karma pa, then the dorje and stupa might be considered as gendered symbols representing father and mother, who are both needed for the conception (Young 1999, 84). However, male and female in tantric Buddhism have many symbolic meanings such as the unity of compassion (male) and wisdom (female), or the unity of bliss (male) and emptiness (female) and the like. In this way, the unity of male and female also stands for full enlightenment, namely that of the Karma pa. Thus, this whole range of symbolism can be applied here. Each one of the three objects might also be seen as representing one of the three kāyas of a buddha, here attributed to the Karma pa. In this way the statue represents the nirmānakāya, the emanation body, the dorje represents the sambhogakāya, the enjoyment body, and the stupa stands for the dharmakāya, the truth body. Another possibility would be to relate the three objects to the three upper chakras representing body, speech and mind, since a Buddha statue obviously represents the Buddha's body and a stupa

79 See also Young 1999, 84. For an extensive explanation of the symbolic meaning of the dorje, see Beer 2003, 87ff.

${ }^{80}$ Young 1999, 83. For an extensive explanation on the symbolic meaning of stupas, see Beer 1999, 127ff. 
represents the Buddha's mind, although I could not find a clear reference that a dorje might symbolise the Buddha's speech. There is a vast variety of symbolism to it, but most essentially it stands for the "indestructible state of enlightenment," hence the Buddha's mind (Beer 1999, 233). However, certain deities are depicted wearing a chain of dorjes around their neck "symbolising the purification of speech" (Beer 1999, 239). In this way, it can also be related to the speech centre.

After the conception, Karma pa's mother is described as having tantric experiences such as blazing warmth and clear light without effort, and as having countless visions in reality, dreams and meditation. This both demonstrates the mother's high attainments as well as the Karma pa's influence while in her womb. ${ }^{81}$ During the course of the pregnancy there are several mentions of unusual interaction with the foetus. In the third month of pregnancy Karma pa practises yogic exercises in the womb and in the sixth month he utters mantras and syllables, again a sign meant to underline how extraordinary the Karma pa is. Here it is arguable, if the uttering of mantras should rather be interpreted as a wonder worked by the Karma pa or as an "auditive vision" experienced by the mother and other people.

Karma pa's mother also had a vision of Vajrayogini prophesying that the Karma pa was in her womb. This shows again her spiritual attainment and her close connection to the Karma pa, as well as the fact that she was very conscious of who the foetus in her body was. Likewise, she also had visions of Avalokiteśvara dwelling in her heart centre and as a joint of her middle finger. Karma pa is generally considered as an emanation of Avalokiteśvara. Therefore, the vision was eventually a vision of her future son, the Karma pa. In the parents" next vision it is said that a "white man will blow a large conch which will be heard everywhere."

The "white man" can again be identified with Avalokiteśvara - who has a white complexion - and, therefore, with the Karma pa. The blowing of the "large conch that will be heard everywhere" might be a symbol for the teaching activity of the Karma pa, which will reach everywhere.

They also had a vision to go to rNgod A la, which is in the region of the future place of birth. In the current paragraph, i.e., before going to rNgod A la, at the time of conception the parents stayed together in O rgyan ri khrod.

${ }^{81}$ See also Verhufen 1992, 50, who reports similar appearances from the mother of the Eighth Karma pa and who concludes that a high master can cause occurrences like this. Nevertheless, I think that at the same time, it is meant to show the attainments of the mother. 


\subsection{Wrapping up the events in place and time from before the conception until arrival at the future place of birth}

This paragraph wraps up different events in place and time and touches on the following topics: ${ }^{82}$

- The father receives a dream prophesy to go to O rgyan ri khrod to benefit beings;

- At the arrival the mother has a dream vision of the Karma pa as a boy;

- The mother has pure visions beyond limits and visions to be inseparable from the Karma pa all the time;

- A prophecy to go to sPyi mda' in the rNgod area reoccurs repeatedly; dreams of auspicious signs connected to the future birthplace;

- The parents go to the place of the prophecy and recognise it as sPyi mda'i mkhar.

This paragraph starts with a retrospective and then catches up with the preceding paragraph: it is said, that "the father resided in the lower South in order to practice" and that he received a dream prophesy to go to O rgyan ri khrod. It is not stated, where the mother stayed at that time, but eventually both future parents go to this place - O rgyan ri khrod, the place of the conception, described in the previous paragraph.

There the mother has several visions of the Karma pa, in particular she sees him as a "boy with whitish skin" where the skin colour might again be an allusion to Avalokiteśvara. "According to the Tibetan medical tantras the onset of puberty occurs around the age of [...] sixteen for a boy" (Beer 1999, 139-40). For this reason, in Tibetan iconography, tantric deities are usually depicted with sixteen-year old bodies, especially when in union (Beer 1999, 140). The fact that she sees Avalokiteśvara as a boy might be due to this or because he represents the Karma pa, who will be born to her as a child.

It is said that she had limitless pure visions and visions of being inseparable from the Karma pa all the time. This again summarises the events of the previous paragraph.

At the end of the preceding section, the parents have a vision to go to rNgod A la. Here it is said that they have again and again prophecies to go to sPyi mda' in the rNgod area. Then it is said that they finally go to the prophesied place which is here called sPyi mda'i mkhar. Considering the context all three place names must more or less refer to the same place or

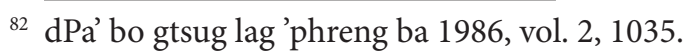


at least the same area (the rNgod area), probably getting more and more specific. It seems that this paragraph wraps up the preceding section and puts the events into a greater context in place and time.

\section{Conclusion}

In the introduction I argue that the secret level (Tib. gsang ba'i rnam thar) of the rnam thar genre is of exceptional importance for the practitioner in terms of inspiration and developing devotion towards the lama. Here, I particularly highlight the role of visionary experiences, which are told in such texts. As an example, I present an annotated translation, analysis and edition of a so far untranslated section of the rnam thar of the Seventh Karma pa from the Chos 'byung mkhas pa'i dga' ston where such visionary experiences are described.

It would be interesting to systematically compare this text with others containing descriptions of visionary experiences, especially to those related to other Karma pas - both concerning visions of the Karma pas themselves, as well as visions of other people before the birth of other Karma pas. The secret level of life stories does not only consist of visionary experiences, which is the focus of this paper. Another focus could be the aspect of miracles or other auspicious signs and events. Several of such are described in the continuation of the Seventh Karma pa's life story at the time of his birth. I prepared another paper, which forms part 2 of this essay, and where I analyse the auspicious signs and events described there by comparing them with the Buddha's birth story as presented in the Lalitavistara Sutra and by explaining them based on research conducted on Vajrayana symbolism (Dell forthcoming a).

\section{Appendix: Edition}

\subsection{Introduction to the edition}

All textual witnesses of the mKhas pa'i dga' ston that I could identify are based on the lHo brag printing blocks. According to Richardson (1959, x), referring to the colophon of these blocks, they were originally stored in gNas bzhis, a bKa' brgyud monastery, in $\mathrm{lHo}$ brag, but later on were moved to $\mathrm{lHa}$ lung monastery, also in 1 Ho brag, from where he and Lokesh Chandra obtai- 
ned some copies. ${ }^{83}$ I could not find any evidence, or hint, for the existence of other printing blocks of the mKhas pa'i dga'ston.

I could identify several textual witnesses of the mKhas pa'i dga'ston, of which the most interesting and original one is a reproduction of prints from the 1 Ho brag blocks from Rumtek Monastery in two volumes from $1980 .{ }^{84}$ This reproduction is also available via BDRC, and I took this as the starting point for the edition I provide in here. Several other prints or reproductions from those printing blocks are available. However, as all are produced from the same printing blocks, I do not expect any added value considering them and, therefore, I have omitted them for the edition. All other textual witnesses have been derived from the texts of these printing blocks more recently.

Lokesh Chandra already published the mKhas pa'i dga'ston in four volumes between 1959 and $1965 .{ }^{85}$ This edition is based on a print from the lHo brag blocks he had made, and was copied in handwriting using $d b u$ can script. ${ }^{86}$

rDor je rgyal po made a modern edition in a book format published by Mi rigs dpe skrun khang, first in 1986 in two volumes, then in 2006 in one volume, and again in 2015 in one volume. ${ }^{87}$ The first two are available via $\mathrm{BDRC}$, while the third is subject to restricted access in BDRC. ${ }^{88}$ Since all three editions are from the same publishing house and editor, I assume that the 2006 and 2015 editions do not add information to the 1986 edition. I found references to further modern book editions from other publishers, which seem rather difficult to obtain. Therefore, apart from the reproduction of the original block print $\left(\mathrm{A}^{89}\right)$ and Chandra's handwritten version $\left(\mathrm{C}^{90}\right)$, I only considered the 1986 edition $\left(\mathrm{B}^{91}\right)$ for the edition provided here..$^{92} \mathrm{My}$

${ }^{83}$ Richardson (1959) or Chandra (1959), respectively, do not mention when that was, but it must have been before Chandra issued his edition, that is before 1959. I have no information as to whether these blocks still exist today.

${ }^{84}$ dPa' bo gtsug lag 'phreng ba 1980.

${ }^{85} \mathrm{dPa}$ ' bo gtsug lag 'phreng ba 1959-1965.

${ }^{86}$ Chandra 1959, vii, and Richardson 1959, x.

87 dPa' bo gtsug lag 'phreng ba 1986, 2006, and 2015.

${ }^{88}$ Buddhist Digital Resource Center, https://www.tbrc.org/\#!footer/about/newhome (Accessed: 22.12.2019).

${ }^{89} \mathrm{dPa}$ ' bo gtsug lag 'phreng ba 1980, vol. 2, 186-88.

${ }^{90}$ dPa' bo gtsug lag 'phreng ba 1959-1965, vol. 2, 538-39.

91 dPa' bo gtsug lag 'phreng ba 1986, vol. 2, 1033-35.

92 These three editions are also mentioned in Martin and Bentor 1997, 88-89. For a much more extensive survey of the textual witnesses of the mKhas pa'i dga'ston and an introduction into the work as a whole, see Dell forthcoming b. 
impression is that Chandra's version is rather close to the block print reproduction, with only a few rare differences in spelling. However, it was also useful to consider rDo rje rgyal po's edition, since in many places the latter corrects spelling mistakes or non-standard spellings from the original. For instance, texts $\mathrm{A}$ and $\mathrm{C}$ frequently read gsung where one would expect gsungs. In some cases text B corrects misspellings of text A, in other cases it has new misspellings. If there are differences, I indicate in the apparatus, which variants there are in which text, and for which reading I decided. For instance "gsungs B] gsung A, C" means that I decided to read gsungs according to text $\mathrm{B}$, while texts $\mathrm{A}$ and $\mathrm{C}$ actually read gsung. In some rare cases I decided to emend the text to a variant that is found in neither of the texts, indicated by "em." for emendatio, e.g. "sha rtsi em.] sha rtsa A, B, C." Generally, there are no significant differences in the section I studied. The guiding theme of the edition is classical Tibetan grammar and orthography. In the edition below, the page numbers of all three texts are indicated in brackets, if a new page starts.

\subsection{Edition}

(A, vol.2, p.186, l.3; B, vol.2, p.1033, l.20; C, vol.2, p.538, 1.4)

mtshur phu 'jam dbyangs chen pos kyang bya lo zla ba bdun pa'i skabs shig93 ja gral ba mang du yod pa zhig ${ }^{94}$ la nga'i rmi lam ltar na da res sprul sku'i yab la dpal grub bya ba zhig yong ba 'dug gsungs ${ }^{95}$ /

kun mkhyen ${ }^{96}$ ban sgar bas kyang mtshur phu nas shar phyogs drang por sprul sku 'byon zhes lung bstan/

(B, p.1034) sku bltams ${ }^{97}$ pa'i yul der dri bzang gi ngad me tog gi char skya ser thams cad la rmi lam khyad par can mang du byung bas ci lta zhig zhes gleng/

de ltar gdul bas' $i$ dus mkhyen zhing sngon lung bstan pa'i yab yum yul dang bcas pa la gzigs te thog mar O rgyan ri khrod bya bar yab sngags spyod kyi grub thob grags pa dpal grub dang yum rang bzhin gyi rnal 'byor ma jo dar bza' lha mo skyid ces bya ba gnyi ga sbas pa'i rnal 'byor dbang phyug

\footnotetext{
${ }^{93}$ shig B] $\operatorname{cig} \mathrm{A}, \mathrm{C}$.

${ }^{94}$ zhig B] cig A, C.

${ }^{95}$ gsungs $\left.\mathrm{B}\right]$ gsung A, C.

${ }^{96}$ kun mkhyen A, C] kun mkhyed B.

${ }^{97}$ sku bltams $\left.\mathrm{B}, \mathrm{C}\right]$ sku bltam $\mathrm{A}$.

98 ba A, B] pa C.
} 
tu $u^{99}$ bzhugs pa na rnal 'byor gyi rgyud ltar sgo drug gi mdzad ${ }^{100}$ pas 'gro ba thams cad rnam snang du bkod cing rnal 'byor bla na med pa'i mngon par byang chub pa'i ye shes rnam pa lnga las yum gyi lhums pho brang dag pa rnam snang gi ngo bor rigs thams cad pa'i gzugs sku'i gtso bor bzhengs te skal ldan rnal 'byor gi dbang phyug ri rab kyi rdul snyed smin grol du mdzad la tshu rol mthong ba pa skal ba cung zad dge ba rnams kyi ngor ni yum gyi lhums su zhugs pa dang yum gyi kha dog (A, p. 187) dang spyod tshul sogs kyang sngon las ches 'phags par snang ba zhig go/

/de'i tshe yum gyi sa ${ }^{101}$ cung zad g.yo zhing lus 'ja' tshon gyis rtag par 'khor/

/bde drod 'bar 'od gsal rtsol med du ${ }^{102}$ zin/

rmi lam du'ang rje mthong ba don ldan dang yang yang mjal/

rgyab ri la brag lha mgon po rang byon 'dug pa khong rang gi dngos grub yin zer ba dang/ ring bsre ${ }^{103}$ gyi rdo rje 'chang gi sku dang gser gyi rdo rje dang shel gyi mchod rten rnyed $\mathrm{pa}^{104}$ pang $^{105} \mathrm{khug}$ tu ${ }^{106}$ bcug pa dang/

nyi zla mang du shar ba sogs dag snang 'ba' zhig rmis ${ }^{107 /}$

zla ngo gsum pa'i tshes brgyad la nam mkhar rol mo'i sgra mang po lan gsum du grag/

lhums su 'phrul 'khor lan gsum mdzad pas yum gyi sku g.yos/

zla ngo drug gi nyi shu brgyad la yig drug gsung ba yum gyis gsal por thos/ de phyin dus bzang thams cad la A' li k'a li dang yig drug gsung ba nye 'khor ba kun gyis thos/

yum shing 'thu ba na brdabs phog pas A na na ci byed pa yin (B, p.1035) gsungs ${ }^{108} /$

yum btung ba 'thung tshe 'khrul 'khor mdzad pas btung ba bo/

bu mo zhig gis zhwa nag byin zhing rdo rje rnal 'byor mas khyod kyi lus la karma pa 'khrung rgyu yod zer thugs ka stong pa'i nang na spyan ras (C, p.539) gzigs zhal gcig phyag bzhi pa sku mdog dkar po zhig ${ }^{109}$ 'dug par snang/

\footnotetext{
99 tu B] $d u \mathrm{~A}, \mathrm{C}$.

$\left.{ }^{100} \operatorname{mdzad} \mathrm{B}\right] \operatorname{mdzod} \mathrm{A}$.

${ }^{101}$ gyi sa A, B] gyis C.

${ }^{102}$ du A] tu B, C.

${ }^{103}$ ring bsrel $\mathrm{B}$ ] ring srel $\mathrm{A}, \mathrm{C}$.

${ }^{104}$ rnyed pa B] brnyed pa A, C.

${ }^{105}$ pang em.] pung $\mathrm{A}, \mathrm{B}$, bud $\mathrm{C}$.

$\left.{ }^{106} t u \mathrm{~B}\right] d u \mathrm{~A}, \mathrm{C}$.

${ }^{107}$ rmis B] rmi A, C.

${ }^{108}$ gsungs $\left.\mathrm{B}\right]$ gsung A, C.

${ }^{109}$ zhig B] cig A, C.
} 
phyag g.yas pa'i gung mdzub kyi tshigs gsum rigs gsum mgon por snang ba la spyan ras gzigs shin tu ${ }^{110}$ gsal zhing gzhan gnyis cung mi gsal bar gzigs/ de sogs dag pa'i snang ba'i dgnos nyams rmi lam gyi snang ba ni mtha' yas/ mi dkar po zhig'11 gis dung chen po zhig'112 'bud cing 'di phyogs thams cad du ${ }^{113}$ grag par 'gyur ro/ khyod 'dir mi14 'dug rngod A la na song zhig zer/

yab de sngon lho smad na sgrub pa la bzhugs pa'i tshe rmi lam na bla mas lung bstan te ${ }^{115} \mathrm{O}$ rgyan ri khrod (A, p.188) du $\mathrm{u}^{116}$ song zhig 'gro don mtha' yas pa 'byung ngo zhes byung bas de ma thag byon pa na yum la yang lung bstan byung ste der byon tshe dri bzang gi ngad kyis phyogs thams cad khyab/

rmi lam du bu sha rtsi1 ${ }^{117} d$ kar ba zhig 'dug pas chos rje karma pa yin zer ba dang/ dag snang mtha' yas shing ${ }^{118}$ dus rtag par rje karma pa dang mi 'bral ba'i snang ba shar/

rngod spyi mdar song zhig par yang yang lung bstan pa byung/

phyis sku bltams ${ }^{119}$ pa'i sa der nyi zla zung zhig'20 'dug pa dang gser sbram rnyed ${ }^{121}$ pa sogs gnyi ga la rmis ${ }^{122}$ te rngod $d u^{123}$ byon rmi lam du byung ba'i gnas de spyi mda'i mkhar yin par shes nas der ${ }^{124}$ bzhugs/

\section{Bibliography}

\section{Tibetan literature}

dPa' bo gtsug lag 'phreng ba (1504-1564/1566). 1959-1965. Mkhas pahi dgah ston by Dpah-bo-gtsug-lag 'phreng-ba (4 volumes), Lokesh Chandra (ed.). Śatapitaka Series no. 9[4]. New Delhi: International Academy of Indian Culture. BDRC, W1KG24245.

\footnotetext{
${ }^{110}$ shin tu B, C] shin du A.

${ }^{111}$ zhig B] cig A, C.

${ }^{112}$ zhig B] cig A, C.

$\left.{ }^{113} d u \mathrm{~B}\right] t u \mathrm{~A}, \mathrm{C}$.

${ }^{114}$ mi ’dug B] ma 'dug A, C.

${ }^{115}$ te $\left.\mathrm{B}\right]$ ste $\mathrm{A}$.

$\left.{ }^{116} d u \mathrm{~B}\right] t u \mathrm{~A}, \mathrm{C}$.

${ }^{117}$ sha rtsi em.] sha rtsa A, B, C.

${ }^{118}$ shing B] cing A, C.

${ }^{119}$ bltams B] bltam A, C.

${ }^{120}$ zhig B] cig A, C.

${ }^{121}$ rnyed $\mathrm{B}$ ] brnying $\mathrm{A}$, brnyed $\mathrm{C}$.

${ }^{122}$ rmis $\left.\mathrm{B}\right]$ brmis $\mathrm{A}, \mathrm{C}$.

$\left.{ }^{123} d u \mathrm{~B}\right] \mathrm{tu} \mathrm{A}, \mathrm{C}$.

${ }^{124}$ shes nas $\left.\operatorname{der} \mathrm{A}, \mathrm{B}\right] \operatorname{der} \mathrm{C}$.
} 
---. 1980. Chos 'byung mkhas pa'i dga' ston (2 volumes). Reproduced from prints from

1 Ho brag blocks from Rumtek Monastery. Delhi: Delhi Karmapa Chhodhey Gyalwae Sungrab Partun Khang. BDRC, W28792.

---. 1986. Chos 'byung mkhas pa'i dga' ston (2 volumes), edited by rDo rje rgyal po. Bejing:

Mi rigs dpe skrun khang. BDRC, W7499.

---. 2006. Chos 'byung mkhas pa'i dga' ston, edited by rDo rje rgyal po. Bejing: Mi rigs dpe skrun khang. BDRC, W1PD96069.

---. 2015. Chos 'byung mkhas pa'i dga' ston, edited by rDo rje rgyal po. Bejing: Mi rigs dpe skrun khang. BDRC, W8LS19006.

Mar pa lo tsā ba (1002/1012-1097/1100), and dPal 'byor don grub (1427-1489). 1995. rTsa rlung 'phrul 'khor, edited by Thub bstan phun tshogs. Khreng tu'u: Si khron mi rigs dpe skrun khang. BDRC, W26185.

Yísūn, Zhāng 张怡䔉, ed. 1985. Bod rgya tshig mdzod chen mo / Zàng-Hàn dà cídiăn 藏汉 大辞典 (3 volumes). Beijing: Mi rigs dpe skrun khang.

\section{Western literature}

Barron, Richard. 2003. The Autobiography of Jamgön Kongtrul, A Gem of Many Colors. Ithaca-Boulder: Snow Lion.

Beer, Robert. 1999. The Encyclopedia of Tibetan Symbols and Motifs. Boston: Shambala. ---. 2003. The Handbook of Tibetan Buddhist Symbols. Chicago-London: Serindia.

Buddhist Digital Resource Center (BDRC). Accessed December 22, 2019 to February 5, 2020. Chandra, Lokesh. 1959. "Preface." In Mkhas pahi dgah ston by Dpah-bo-gtsug-lag 'phreng-ba (4 volumes), vol. 1, edited by Lokesh Chandra, vii-viii. New Delhi: International Academy of Indian Culture (Śatapitaka Series, 9[4]).

Chaoul, M. Alejandro. 2007. "Trulkhor: The Magical Movement of Tibet." Shambala Sun (March): 70-71. Accessed July 25, 2015. http://www.kahunavalley.org/shambhalasun-mar07.posturesmovements.pdf.

Choegyal Gyamtso Tulku. 2000. "Foreword." In The Divine Madman, The Sublime Life and Songs of Drukpa Kunley. Translated by Keith Dowman, Sonam Paljor, 21-23. Varanasi-Kathmandu: Pilgrims Publishing.

Delehaye, Hippolyte. 1962. The Legends of the Saints. New York: Fordham University Press. Dell, Dominik. 2020. "Tibetan Buddhist Masters between Two Lives: A Closer Look at the Genre of Bar do'i rnam thar Using the Example of the Seventh Karma pa, Chos grags rgya mtsho (1454-1506)." Polish Journal of the Arts and Culture, n.s., 11, no 1: 41-63.

- - . 2021. "Birthplace of the Seventh Karma pa, Chos grags rgya mtsho (1454-1506):

Description Draws from Tibetan Geomancy and Pilgrimage Guidebooks." Revue d'Etudes Tibétaines 58 (April): 81-102.

---. Forthcoming a. "Birth of a Tibetan Buddhist Master, Part 2: Auspicious Signs and Events at the Birth of the Seventh Karma pa, Chos grags rgya mtsho (1454-1506)." Polish Journal of the Arts and Culture, n.s., 13, no 2.

---. Forthcoming b. " "Feast of the Wise': Author, Structure and Textual Witnesses of the $16^{\text {th }}$ Century Religio-Historical Work Chos 'byung mkhas pa'i dga' ston by the Second dPa bo, gTsug lag phreng ba (1504-1566)." Revue d'Etudes Tibétaines (October 2021). 
Dharmachakra Translation Committee. 2013. The Play in Full, Lalitavistara. 84000: Translating the Words of the Buddha. Accessed July 21, 2020. https://read.84000.co/translation/ toh95.html.

Duff, Tony. 2009. The Illuminator Tibetan-English Encyclopedic Dictionary (5.17 ed.). Kathmandu: Padma Karpo Translation Committee.

Evans-Wentz, Walter Yeeling, ed. 1969. Tibet's Great Yogi Milarepa: A Biography from the Tibetan. Oxford: Oxford University Press.

Gardner, Alexander. 2011. Jampel Zangpo. Treasury of Lives. Accessed February 2, 2020. https://treasuryoflives.org/biographies/view/Jampel-Zangpo/7130.

Goldstein, Melvyn C., T.N. Shelling, and J.T. Surkhang, eds. 2001. The New Tibetan-English Dictionary of Modern Tibetan. Berkeley (Los Angeles): University of California Press.

Gyatso, Janet. 1981. "The Literary Transmission of the Traditions of Thang-stong rgyal-po: A Study of Visionary Buddhism in Tibet." PhD dissertation, University of California, Berkely.

Jamgön Kongtrul Lodrö Thayé. 2003. The Autobiography of Jamgön Kongtrul, A Gem of Many Colors. Translated and edited by Richard Barron. Ithaca-Boulder: Snow Lion.

Jäschke, Heinrich August. 1881. A Tibetan-English Dictionary: With Special Reference to the Prevailing Dialects; To Which Is Added an English-Tibetan Vocabulary. Reprint. Delhi: Motilal Barnasidass Publisher, 1998. First published in London.

Khenpo Ngawang Pelzang. 2004. A Guide to the Words of My Perfect Teacher. Boston: Shambhala.

Khenpo Tsewang Dongyal. 2008. The Life and Legacy of H.H. Dudjom Rinpoche. Ithaca: Snow Lion.

Kieschnik, John. 2004. "Miracles.” In Encyclopedia of Buddhism, edited by Robert E. Buswell, vol. 1, a-1, 541-44. New York: Macmillan.

Lipman, Kennard. 1987. "The Dynamic Yoga of Tibet: Combining Asanas, Breathing Exercises, and Flowing Movements, Yantra Yoga Aims to Return Us to Our 'Natural State."' Yoga Journal 74 (May): 46-49.

Martin, Dan, and Yael Bentor. 1997. Tibetan Histories: A Bibliography of Tibetan-language Historical Works. London: Serindia Publications.

Nebesky-Wojkowitz, René de. 1996. Oracles and Demons of Tibet-The Cult and Iconography of the Tibetan Protective Deities. Reprint. Delhi: Book Faith India. First published in 1956.

Oxford Dictionaries. “Hagiography.” Accessed January 15, 2020. https://www.lexico.com/ definition/hagiography.

Ray, Reginald A. 1980. "Introduction." In The History of the Sixteen Karmapas of Tibet by Karma Thinley, 1-20. Boulder: Prajña Press.

Rheingans, Jim. 2010. "Narratives of Reincarnation, Politics of Power, and the Emergence of a Scholar: The Very Early Years of Mikyo Dorje." In Lives Lived, Lives ImaginedBiography in the Buddhist Tradition, edited by Linda Covill, Ulrike Roesler, and Sarah Shaw, 241-98. Boston: Wisdom Publications.

--_. 2014. "Narratology in Buddhist Studies: Dialogues about Meditation in a Tibetan Hagiography." In Narrative Pattern and Genre in Hagiographic Life Writing: Comparative Perspectives from Asia to Europe, edited by Stephan Conermann, and Jim Rheingans, 69-112. Berlin: EB-Verlag. 
Richardson, Hugh Edward. 1959. "Foreword." In Mkhas pahi dgah ston by Dpah-bo-gtsug-lag 'phreng-ba (4 volumes), vol. 1, ix-xi, edited by Lokesh Chandra. New Delhi: International Academy of Indian Culture (Śatapitaka Series, 9[4]).

Rigpa Wiki contributors. Six Doors of Negative Action. Rigpa Wiki. Accessed January 26, 2020. https://www.rigpawiki.org/index.php?title=Six_doors_of_negative_action.

Robinson, James Burnell. 1996. "The Lives of Indian Saints: Biography, Hagiography and Myth." In Tibetan Literature-Studies in Genre, edited by José Ignacio Cabezón, and Roger R. Jackson, 57-69. Ithaca-New York: Snow Lion.

Roesler, Ulrike. 2014. "Operas, Novels, and Religious Instructions: Life-stories of Tibetan Buddhist Masters between Genre Classifications." In Narrative Pattern and Genre in Hagiographic Life Writing: Comparative Perspectives from Asia to Europe, edited by Stephan Conermann, and Jim Rheingans, 113-40. Berlin: EB-Verlag.

Schuh, Dieter. 2010. "Tshurphu-Schule (mtshur-lugs) der Tibetischen Astronomie." In Tibet-Encyclopedia. Accessed February 6, 2020. http://www.tibet-encyclopaedia. de/tshurphu-schule.html.

Tsang Nyön Heruka. 1982. The Life of Marpa the Translator, Seeing Accomplishes All. Translated by Nalanda Translation Committee under the direction of Chogyam Trungpa. Boulder: Prajñā Press.

Verhufen, Gregor. 1992. "Die Biographien des achten Karma-pa Mi-bskyod rdo-rje und seines Lehrers Sangs-rgyas mNyan-pa Rin-po-che. Ein Beitrag zur Geschichte der Karma-bKa'-brgyud-pa-Schulrichtung des tibetischen Buddhismus." MA dissertation, University of Bonn, Germany.

Vostrikov, Andrew Ivanovich. 1994. Tibetan Historical Literature. Abington (Oxon, UK): Routledge. Willis, Janice Dean. 1985. "On the Nature of Rnam-Thar: Early dGe-lugs-pa Siddha Biographies." In Soundings in Tibetan Civilization, edited by Barbara Nimri Aziz, Matthew Kapstein (eds.), 304-19. New Delhi: Manohar.

---. 1995. Enlightened Beings: Life Stories from the Ganden Oral Tradition. Boston: Wisdom Publications.

Young, Serenity. 1999. Dreaming in the Lotus: Buddhist Dream Narrative, Imagery \& Practice. Boston: Wisdom Publications. 